\title{
Literary Text as a Unit of Culture in the Classes of Russian as a Second Language
}

\author{
Zulfiya Firdinatovna Yusupova ${ }^{1}$ \\ ${ }^{1}$ Kazan Federal University, Kazan, Russian Federation \\ Correspondence: Zulfiya Firdinatovna Yusupova, Kazan Federal University, 420008, Kazan, Kremlevskaya \\ Street, 18, Russian Federation. E-mail: Usupova.Z.F@mail.ru
}

\author{
Received: August 11, 2014 Accepted: October 29, 2014 Online Published: February 25, 2015 \\ doi:10.5539/ass.v11n6p171 URL: http://dx.doi.org/10.5539/ass.v11n6p171
}

\begin{abstract}
This article discusses some features of using literary text as a unit of culture as didactic material in the classes of Russian as a second language. The theoretical premise of our study is the postulates of modern linguistics, functional stylistics, cultural linguistics, and linguodidactics. This scientific paper presents the interrelation of the literary text and culture, the criteria for the selection of the texts, and describes some aspects of the work with literary text in teaching Russian as a second language The author proposes a methodological description of the use of literary texts in teaching Russian as a foreign language. The article concludes that the literary text is important cultural information that should be considered while studying the Russian language.
\end{abstract}

Keywords: Russian as a second language, literary text, cultural text, cultural information, linguodidactics

\section{Introduction}

Modern linguistic education emphasizes the interrelated study of language and culture, due to the communicative and cultural language teaching conception (Vereschagin, 2005; Shakirova, 2008; Bystrova, 2007; Soureshjani, 2013; Watson, 2002; Karabulatova, 2013; Ter-Minasova, 2008; Zamaletdinov, 2012; Fattakhova, 2014 etc.). In this regard, studies on intercultural and interlingual communication, cultural linguistics and ethnolinguistics, ethnopsycholinguistics, cognitive linguistics, comparative typology of languages and cultures, and the problem of text and ethnopedagogics and etnomethodic, in particular, are currently of interest. It should be noted that the results of linguistic research are of practical importance for the teaching of language methods. In the process of teaching Russian as a second language, the interrelation between language and culture is transmitted by literary texts, which are the main didactic material. It is well known that the text is a unified communicative, cultural, informative and semantic, compositional and linguistic entity.

This article will examine some features of the literary text's use as a unit of culture, which is a didactic material in the classes of Russian as a second language.

\section{Method}

The study of the text as a unit of culture has attracted and continues to attract the attention of many researchers (Bakhtin, 1997; Deykina, 1998; Bolotnova, 2009 etc.).

Scientists concerned with such questions as what is the text of which characteristics of text are most important, which definition of the text is the most comprehensive, how through the text can be translated the culture, how to select texts in teaching Russian language and others. According to scientists, the greatest cultural information has artistic text. In this regard, we analyzed the scientific and methodological literature in terms of lingua methodic lighting it, the specifics of work with literary texts, but also studied the textbooks (textbooks and manuals) to determine the place assigned to it on cultural (artistic) texts.

In the modern methods of teaching Russian as a foreign language, literary text has a special place as a unit of culture, a form of communication and a didactic material, which have a great educational and aesthetic value. Some possibilities of the literary text are used for training, upbringing and initiation to Russian culture are considered in the studies of (Sayakhova, 2010; Hodyakova, 2011; Maslova, 2012; Zakirova, 2013; Mukhametshina, 2014 etc.).

It is well known that national and cultural peculiarities are brightly shown in literary texts. Literary texts are a 
source of culture and contain not only lexical and grammatical material, but also rich cultural information. In this regard, in modern linguistics and linguomethodic the approach to the text has become relevant as a cultural phenomenon, and is included in the scientific use of the term "cultural texts." A. Hodyakova defines cultural texts as "culturally-relevant texts, reflecting historical and cultural values of the people, their spirituality, aesthetic content, form, structure and lexicology. These texts often describe cultural objects (interpretive and commentary), artifacts, language phenomena, traditions of the people, religious rituals, social rituals, holidays, biographies of cultural personalities, historical and significant events or natural phenomena, providing an emotional and moral impact on the reader (listener), evoking a certain sense of goodness, justice, or indignation " (Hodyakova, 2011, p. 79). As a rule, cultural texts represent phraseological units, aphorisms, proverbs and sayings as a generalization of the historical experience of human life. The researchers L. G. Sayakhova call units of culture linguoculturems. The words, idioms, proverbs, sayings, folk omens, texts, and grammatical categories are related to them. The selection of the training content (hence, for linguistic and cultural analysis) is important for the formation of the students' linguistic and cultural competence in the study of the text. It should be done in accordance with the following criteria, which have been developed in linguistics: descriptive, evaluative, normative, spiritual, dialogic, informational, symbolic, and typological. Each of them is important in the formation of the students' linguistic and cultural competence. These criteria for the selection of educational material can determine the nature of didactic material - special texts (linguoculturem), reflecting the history of language and culture. A cultural approach to the study of literary text allows researchers to reveal the relation of the text as a communicative unit of a higher level with culture: 1) the text is generated by a certain social and cultural situation; 2) the text is generated in the context of time and in a particular cultural space, functions as a collective cultural memory, and reflects trends of the society development; 3 ) any text represents the author, the specific linguistic personality, who is a native speaker and of his culture's time; 4) the units of all language levels are presented in any text with their particular national and cultural components. These components include national and specific vocabulary (nonequivalent, background, connotative), word - symbols, word - concepts, idioms, etc." (Sayakhova, 2010, pp. 158-159).

\section{Results}

In the process of teaching Russian as a second language the use of literary text raises a number of questions related to its selection and adaptation. The selection of the text is connected with the age characteristics of students, the saturation of grammar material, the presence of educational potential, and relevance for contemporary students. Adaptation should not touch on the transformation of the literary text and be possibly minimal. Possible reduction of the text's separate components, and their exemption is shown by ellipsis. Textual material is not often extracted from literary works. It is often extracted from the existing educational literature (text books, collections of dictations, didactic material, etc.), where there are mistakes.

Following N. S. Bolotnova, we believe, that the selected texts must meet these criteria: 1) "the text should educate, i.e. meet the moral, ethical and aesthetic requirements; 2) convey new knowledge, i.e. perform an informative function;

3) impact the student's mind and heart, i.e. carry a pragmatic charge; 4) arouse interest to the subject, and enrich the student's specific knowledge, i.e. respond to general didactic requirements (continuity, consistency, clarity, accessibility, etc.)" (Bolotnova, 2009, p. 126).

The literary text as a unique speech unit allows to solve a range of problems, that are set in the teaching process. Besides learning the language system and getting skills of the construction of coherent speech text contributes to solve the students' cognitive problems, moral and aesthetic development, to enhance their speech and thinking activity and the formation of evaluations (how to properly evaluate). In accordance with the theme of the lesson and those concepts which should be learned, the selection of the text should take into account the pupils' age.

Artistic text links such important concepts as language, culture and people. As is well known, being accessory art style, artistic text is different: 1) the unity of aesthetic and communicative functions; 2) a lot of styles; 3 ) extensive use of figurative-expressive language means; 4) the manifestation of the creative personality of the author. In a literary text can be elements of other styles, such as dialect words, jargon, vernacular, vocabulary book, scientific terms, professionalism, archaisms, etc. They are used by the author of the text to create the voice characteristics of actors, local color. In literary texts much attention are drawn to the imagery and expression, expressive and emotive words. It is known that the word in the context of art is both nominative-communicative units and means of creating artistic expression, imagery.

In contemporary textbooks on Russian as a foreign language texts primarily transmit culture. The authors of modern textbooks focus on highly literary texts, saturated, on the one hand, with grammar material, and on the 
other hand, reflecting the cultural values of the Russian and other peoples. Literary texts as a source of culture hold a special place, because the reflection of reality in the linguistic picture of the world, connected with its literary display, is clearly shown in them. Through the text we can form language, communication, cultural knowledge, develop skills, and the text also helps organize the aesthetic, moral and patriotic education of students. Nowadays systematic standardized representation of literary texts with a national and cultural component has been received as the optimal solution by the authors of teaching materials for Russian as a second language under the guidance of E. A. Bystrova, L. Z. Shakirova, and L. G. Sayakhova. By using cultural texts,

L. Z. Shakirova recommends that "we should consider the relation between language and culture in two ways: firstly, how students learn culture and traditions in the process of mastering the communicative function of the Russian language, and secondly, they deepen their knowledge of other cultures by means of the Russian language." (Shakirova, 2008, p. 55). In the Russian textbook of the 6th form (Akhmadullina, 2006) the introduction to Russian culture and Russian worldview is provided primarily by texts and extracts of the best examples from literary works of the Russian writers and poets A. S. Pushkin, N. Nekrasova, L. Tolstoy, A. Kuprin, M. Prishvin, S. Yesenin, K. Paustovsky, G. Skrebitskogo etc. Key concepts are presented in the extracts: Motherland, friendship, labour, home, family, health, nature, book, knowledge, birch etc. They are close and understandable by students. Texts acquaint students with the life of the Russian great personalities of native and world culture: for example, the texts about P. I. Tchaikovsky, V. A. Mozart, I. I. Shishkin, I. E. Repin, A. S. Pushkin, L. N. Tolstoy, A. P. Chekhov, G. Tukae, D. S. Lihachev, etc. Exercises, which we do before and after reading texts, focus on the study of grammatical topics, and also organize discussions about the text.

The teaching material was selected in accordance with the lexical topics in the textbook: "Language is a means of communication and mirror of society's development", "Travelling all over the country, using the map", "The Forest in a person's life," "The Earth is our home", "The World of Music", etc. Thematically selected material allows us to more efficiently organize the work on students' vocabulary enrichment in the Russian lessons.

The genres of folklore have a worthy place in the textbooks of Russian language: riddles, proverbs and sayings. It is known that the knowledge of proverbs and sayings acquaints students with folk wisdom, enriches their vocabulary, helps them learn linguistic imagery, develops memory, logical thinking, and creative imagination. The ways of the realization of linguistic and cultural approaches in the teaching literature are represented in the scientific works of Z. F. Yusupova's (see, e.g., Yusupova, 2012).

\section{Discussion}

After the analysis of scientific and methodological literature, textbooks and manuals on Russian language suggests that today linguists and methodologists recognized the importance and value of the literary text as a unit of culture in the process of learning the Russian language. We believe that cultural studies insufficiently realized the cultural studies potential of literary texts in the process of learning the Russian language. Teachers have difficulty in lingo cultural studies text analysis. We propose to consider two passages from the artistic text, which can be discussed with the students in the study of the Russian language.

Cultural texts help expand the cultural horizons of students, enrich the students' vocabulary with the cultural words, and the terms and vocabulary used in the socio-cultural sphere. For example, the text about the Russian oven:

...As I took a closer look, the Russian oven is inconvenient for cooking: cooking is hidden from the cook, and the heat comes to the pot from the different sides unevenly. But because it might have come to our ancestors from the Stone Age, it was heated till the dawn, and kept the food warm all day and slop for cattle, food and water for humans. And it is warm to sleep on. (Solzhenitsyn, 2001, pp. 153-154)

In this extract, the small cultural information about the Russian oven is presented, which performs a symbolic role in the Russian izba (peasant's house). The Russian oven is arranged by taking into consideration the average cold climate, especially in northern Russia. So as it was heated in the morning, the oven kept warm until late night, and let us cooks food for people and feed for cattle. The image of the Russian oven is often found in fairy tales, proverbs and sayings, folk songs, and literary works. All this allows us to formulate a conversation with students about the peculiarities of the Russian oven. For example, the text about the Russian dances:

.....Grandma wasn't dancing, but she was saying something. Here she is going quietly, thinking, rocking, looking around out of hand, and all her big body is swaying hesitantly, legs are groping the road carefully. Suddenly she stopped frightened of something, face quivered. She frowned and immediately lit up with a good friendly smile. She shrank away, giving way to someone, taking someone by her hand; put her head down, froze, listening, smiling merrier - and suddenly she jumped up like a whirling vortex, becoming slimmer, taller, and so it was impossible to look away from her eyes - she was becoming so wildly beautiful and nice in these moments of the 
wonderful change to youth! (Gorkiy, 1979, pp. 231-232)

In this passage, the author shows the mood of the Russian dance, and reveals the soul of Russian people. Russian dance can be slow and fast, solo, pair, and mass. Dance includes round-lays, improvisation, the elements of the quadrille dances and others. We can talk with students about Russian dance as a folk dance, and other dances of the peoples in the world.

In a literary text we find information about national holidays, such as Mardi Gras, Easter, Christmas and others. For example, students can learn about the features of this holiday as Mardi Gras through a passage from a work of art:

"Mardi Gras <... > And evennow feel that word, as it felt when I was a child: bright spots, call causes it in me; blazing furnace, bluish waves in happy hum of the assembled people, bumpy snowy road already oily in the sun, with diving on her merry sleigh with cheerful horses in rosanna, in campanula and bells, with playful harmony busting <...>Mardi Gras, walk! In this broad word and now even for me alive bright joy, beforesadness - before Easter?"(Shmeliov, 2001, p. 223)

By analyzing this text, students find out the value of holiday Mardi Grasfor the Slavic people. Mardi Gras - an ancient national festival farewell of winter and meeting ofspring. It was customary for a week pancakes, each day of Mardi Gras had own value. Besides, in this passage should clarify the meaning of suchwords as people, bumpy road, the horses in rosanna, harmony, Easter.

\section{Conclusions}

The study of some aspects of the literary text's use as a unit of culture in the lessons of Russian as a second language leads to several conclusions. Nowadays in the language teaching (native, Russian and foreign languages) intercultural and cross-language peculiarities are taken into account (for example, Sadykova, 2009; Yusupova, 2014; Shakurova, 2014). It is an undisputed fact that literary text has a great cultural potential. By using the "textual" fund, we can acquaint students with the holidays and traditions of Russian and other peoples, objects of decorative art, folk songs, dances, musical instruments, etc. All these arouse a lively interest in the students to the teaching material, and to the language as a translator of culture. Despite the availability of the texts with cultural content in modern textbooks of Russian language, we believe that their opportunities are not fully realized, therefore cultural texts have more opportunities to be used in Russian language lessons with the aim of forming the language, communication, and cultural competencies, providing the content of the student's speech development, his/her intellectual, moral and spiritual spheres as a way of the creative person's self-realization.

Thus, co-learning of languages and cultures by literary texts generates communicatively developed, culturally educated person, and develops and improves a student's language and communication skills in a contemporary multi-ethnic world.

However, in one article the author has failed to show all the potential uses of artistic text in learning the Russian language. In the future, could explore this topic, show samples of linguistic-cultural analysis of literary texts in the study of such sections of the Russian language like, phonetics, orthoepy, vocabulary and phraseology, morphology and syntax.

\section{Acknowledgments}

The work is performed according to the Russian Government Program of Competitive Growth of Kazan Federal University.

\section{References}

Akhmadullina, F. Y., Khairutdinova, G. A., \& Zakirova, R. Y. (2006). Russian language: Textbook for 6th grade Tatar secondary school. Kazan: Magarif.

Bakhtin, M. (1997). Russian Slovesnost. The Problem of Text in linguistics, philology and other humanities: The Experience of philosophical analysis (pp. 227-249). Moscow: Academia.

Bolotnova, N. S. (2009). Philological analysis of Text. Moscow: Flint: Science (Nauka).

Bystrova, E. A. (2007). Teaching Russian language at school. Cultural function of the Russian language in the system of its teaching (pp.131-155). Moskow: Drofa.

Deykina, A. D., \& Novozhilova, A. D. (1998). Miniature Texts in Russian lessons: A teacher's guide. Moscow: Flint: Science.

Fattakhova, N., \& Kulkova, M. (2014).The Formation of Paroemiology in Russia and Germany. World Applied 
Sciences Journal, 31(5), 935-939.

Gorkiy, A. M. (1979). Collected Works in 16 volumes. Childhood, 8, 204-392. Moscow: Publishing House of "Truth".

Hodyakova, L. A. (2011). Methodic interpretation of text as a cultural phenomenon. Yaroslavl Pedagogical messenger, 2, 76-81.

Karabulatova, I. S., Polivara, Z. V., \& Zamaletdinov, R. R. (2013). Ethno-Linguistic Peculiarities of Semantic Perception of Language Competence of Tatar Bilingual Children. World Applied Sciences Journal, 27, 141-145.

Maslova, V. A. (2012). Russian as a second language: New developments in theory and methodology. A Study of the most important concepts of Russia's culture by foreign background (for example, the concept "family") (pp. 214-220). Moscow: Moscow State Pedagogical Institute.

Mukhametshina, R. F., \& Galimullina, A. F. (2014). Inculcation of Bimental personality in context of cultural dialogue (as examplified by Tatarstan Schools). Middle-East Journal of Scientific Research, 20(12), 2135-2138.

Sadykova, G., \& Dautermann, J. (2009). Crossing cultures and borders in international online distance higher education. Journal of Asynchronous Learning Network, 13(2), 89-114.

Sayakhova, L. G. (2010). Methodology and methodical system of the formation of Turkic speaking students' linguistic and cultural competence in Russian lessons. Ufa, DC: Bashkir State University.

Shakirova, L. Z. (2008). Pedagogical linguistics: Concepts and technology. Kazan: Magarif.

Shakurova, M. M., \& Mirzagitov, R. H. (2014). Linguistic analysis of Tatar language textbooks for non-Russian students. Life Science Journal, 11(10), 674-677.

Shmeliov, I. S. (2001). Year of the Lord: A Tale. Mscow.: International Publishing House "Synergy".

Solzhenitsyn, A. I. (2001). One day of Ivan Denisovich. Stories 60s. centuries. The yard of Matryona (pp. 143-188). SPb.: Publishing House of "ABC's classic".

Soureshjani, K. H. (2013). Culture knowledge and its availability in language teaching and learning in English as a Foreign Language (EFL) contexts. Journal of Languages and Culture, 4, 58-64.

Ter-Minasova, S. G. (2008). War and Peace of the languages and cultures. Moskow: Slovo.

Vereschagin, E. M., \& Kostomarov, V. G. (2005). Language and culture. Moskow: Indrik.

Watson, S. M., \& Houtz, L. E. (2002). Meeting the Academic Needs of Culturally and Linguistically Diverse Students. Intervention in School and Clinic, 37(5), 267-278. http://dx.doi.org/10.1177/105345120203 700502

Yusupova, Z. F. (2012). Realization of cultural and linguistic principles in the teaching of literature in the Russian language for a Turkic speaking audience. Philology and Culture, 2(28), 170-173.

Yusupova, Z. F. (2014). Ways to overcome the cross-language interference at teaching Turkic-speaking attendance in Russian language. Life Science Journal, 11(7), 366-369.

Zakirova, R. Y. (2013). Russian and Comparative paremiology in Tatarstan: Origins and developments: Materials of the International Scientific-Practical Conference. The Study of paronyms as linguoculturem at school (pp. 66-75). Kazan: Publishing House "Pechat - Service XXI Century".

Zamaletdinov, R. R., \& Zamaletdinova, G. F. (2012). Language is the cultural code of a nation and the key to the culture of all mankind. Philology and Culture, 2(28), 49-53.

\section{Copyrights}

Copyright for this article is retained by the author(s), with first publication rights granted to the journal.

This is an open-access article distributed under the terms and conditions of the Creative Commons Attribution license (http://creativecommons.org/licenses/by/3.0/). 